Article

\title{
Amid the COVID-19 Pandemic, Unethical Behavior in the Name of the Company: The Role of Job Insecurity, Job Embeddedness, and Turnover Intention
}

\author{
Ibrahim A. Elshaer $1,2, *$ (D) and Alaa M. S. Azazz ${ }^{3,4, *(D)}$ \\ 1 Management Department, College of Business Administration, King Faisal University, \\ Al-Hassa 31982, Saudi Arabia \\ 2 Hotel Studies Department, Faculty of Tourism and Hotels, Suez Canal University, Ismailia 41522, Egypt \\ 3 Department of Tourism and Hospitality, Arts College, King Faisal University, Al-Ahsa 380, Saudi Arabia \\ 4 Tourism Studies Department, Faculty of Tourism and Hotels, Suez Canal University, Ismailia 41522, Egypt \\ * Correspondence: ielshaer@kfu.edu.sa (I.A.E.); aazazz@kfu.edu.sa (A.M.S.A.)
}

check for

updates

Citation: Elshaer, I.A.; Azazz, A.M.S. Amid the COVID-19 Pandemic, Unethical Behavior in the Name of the Company: The Role of Job Insecurity, Job Embeddedness, and Turnover Intention. Int. J. Environ. Res. Public Health 2022, 19, 247. https://doi.org/10.3390/ ijerph19010247

Academic Editor: Dimitris Zavras

Received: 23 November 2021

Accepted: 13 December 2021

Published: 27 December 2021

Publisher's Note: MDPI stays neutral with regard to jurisdictional claims in published maps and institutional affiliations.

Copyright: (c) 2021 by the authors. Licensee MDPI, Basel, Switzerland. This article is an open access article distributed under the terms and conditions of the Creative Commons Attribution (CC BY) license (https:// creativecommons.org/licenses/by/ $4.0 /)$.

\begin{abstract}
The worldwide economic crisis initiated by the COVID-19 pandemic certainly altered the perception of regular job insecurity dimensions and brought these to the ultimate level. When employees feel insecure, they may decide to participate in unethical behavior in the name of the company to avoid layoff and become retained employees. This study investigated the relationship between job insecurity and unethical organizational behavior through the mediating role of job embeddedness and turnover intention. A total of 685 employees working in five- and four-star hotels and category A travel agents participated in this study. Data were analyzed using structural equation modeling. Job embeddedness and turnover intention were found to be partially mediated by the impact of job insecurity on unethical organizational behavior. Theoretical and practical implications were identified and discussed.
\end{abstract}

Keywords: job insecurity; unethical organizational behavior; job embeddedness; turnover intention; COVID-19; tourism industry

\section{Introduction}

Until the recent outbreak of the COVID-19 virus, which has spread throughout the globe, organizational life in the twenty-first century had never been more challenging. This pandemic, which spread across numerous countries at the same time, has harmed billions of people worldwide [1]. As a response to this pandemic, more than 30 million employees are expected to lose their jobs in the United States [2]. The leisure and hospitality industry was the most impacted, with 7.7 million jobs lost, or $47 \%$ of the total positions worldwide [3]. Prior to the current epidemic, the travel and tourist industry had remarkable resilience, contributing more than $10 \%$ of global GDP and a similar percentage of jobs [4]. However, due to the lockdowns and bans on internal and international travel executed by a large number of countries, this sector is currently the most affected [5]. Many countries' hospitality businesses have begun laying off employees to cope with the massive losses. Marriott International hotel chains ${ }^{\circledR}$ have begun to lay off tens of thousands of employees around the world [6]. Similarly, Airbnb ${ }^{\circledR}$ laid off almost a quarter of its workforce [7]. Even employees who survive the layoffs are apprehensive about their future careers and have a high level of job insecurity under these conditions. According to previous research, job insecurity is one of the most significant hindrance-related stressors [8-10] that has negative impacts on the hospitality industry's desirable work outcomes [11,12]—and causes absenteeism, nervousness [13], and higher turnover intentions [14].

Though job insecurity has been thoroughly researched, further research can explore the specific employee's reactions to adapt and deal with job insecurity $[8,15]$. According to [16], job insecurity can be combined with high achievement to eliminate work withdrawal. 
Additionally, employees with a higher feeling of job embeddedness can use their capabilities to avoid layoff and become retained employees [17]. They may wish to show their managers that they can make a positive contribution to the company, especially in a time when job instability is on the rise [18]. As a result, they may not see any moral boundaries to engaging in unethical behavior actions that are beneficial to the organization [19].

The issue of employees engaging in unethical behavior to contend with the feeling of job insecurity has been previously highlighted in the literature [20]. However, impacted employees could decide to participate in unethical behavior in the name of the organization but contradict the international ethical standards. A salesperson, for example, could exaggerate the characteristics of a product they were selling to a consumer in order to meet their sales target and assist their company to earn more money. Alternatively, an accountant may falsify figures in order to decrease a company's tax liability [21]. By executing these unethical practices in the name of the company, the employee may be perceived as a successful employee by their managers [21].

The current study first explores the relationship between job insecurity and unethical organizational behavior. This relationship is examined in the context of increasing the fear of job loss with the tendency for employees to engage in unethical behavior that provides short-term advantages to the organization. Second, this study tests the mediating role of job embeddedness in the relationship between job insecurity and unethical organizational behavior, and finally, the study also highlights the mediating effects of turnover intention in the relationship between job insecurity and unethical organizational behavior. Though job insecurity has been extensively investigated, further research can explore the specific employee's reactions to adapt and deal with job insecurity $[8,15]$. Thus, this study proposed a model that may contribute to enhancing academics' understanding in which job insecurity affects employees' unethical organizational behavior through the mediating role of job embeddedness and turnover intention.

Testing these relationships has implications for practitioners as well. Employees who participated in unethical organizational behavior in the name of the company can be for personal gains and such behaviors can reduce the reputation of the organization. Therefore, managers amid such a pandemic should avoid sending signals that can promote employees' perceptions of job insecurity.

\section{Literature Review and Hypotheses Development}

\subsection{Job Insecurity and Unethical Organizational Behavior}

Job insecurity is a 'perceptual phenomenon' that focuses on the threat to an individual's current job stability [22]. The authors of [23] propose two dimensions of job insecurity: quantitative 'threats to the job as such' and qualitative 'threats to valued job features'. Quantitative job insecurity emphasizes the predicted job loss caused by intended/unintended organizational signals, or employees' appraisal reports [22]. Qualitative job insecurity explains an employee's perceived future job loss based on their presumed threat [22]. Given the substantial negative impact of the COVID-19 pandemic on the economy, which affects both demand and supply, organizational restructuring through downsizing has become a popular approach. Downsizing is a strategy for cutting and controlling labor expenses (typically by reducing the number of employees or lowering compensation), streamlining operations, and boosting organizational competitiveness [24]. According to researchers $[25,26]$, downsizing could threaten employees and their jobs. Organizational restructure, according to [27], increases employees' job insecurity. Employees may experience employment insecurity as a result of COVID-19. In the same vein, employees often experience stress because of perceived job insecurity. An employees' stress response frequently stimulates employees to participate in unethical behaviors that help to cope with the perceived threat [28]. Employees can participate in unethical organizational behavior by acting in their self-interest or the best interests of the organization.

Organizational unethical behavior is an unethical practice that is intended to benefit the organization rather than the person [21]. For example, supplying incorrect information 
to a customer in order to accomplish the organization's quarterly predetermined goals could be one of these practices.

As proposed by the self-regulation theory $[29,30]$, exercising self-control necessitates the application of a limited number of self-regulatory resources. The application of these self-regulatory systems depletes these resources, reducing a person's ability to demonstrate the self-control required to make ethical decisions. Additionally, when employees' moral resources have been diminished, their cognitive capabilities are drained, and their successive skill to self-regulate is impeded. When employees' self-regulatory resources are depleted, employees may decide to participate in unethical behavior that benefits the organization or themselves. Therefore, the following hypothesis is proposed as shown in Figure 1:

Hypothesis 1 (H1). Job insecurity has a positive significant impact on unethical organizational behavior.

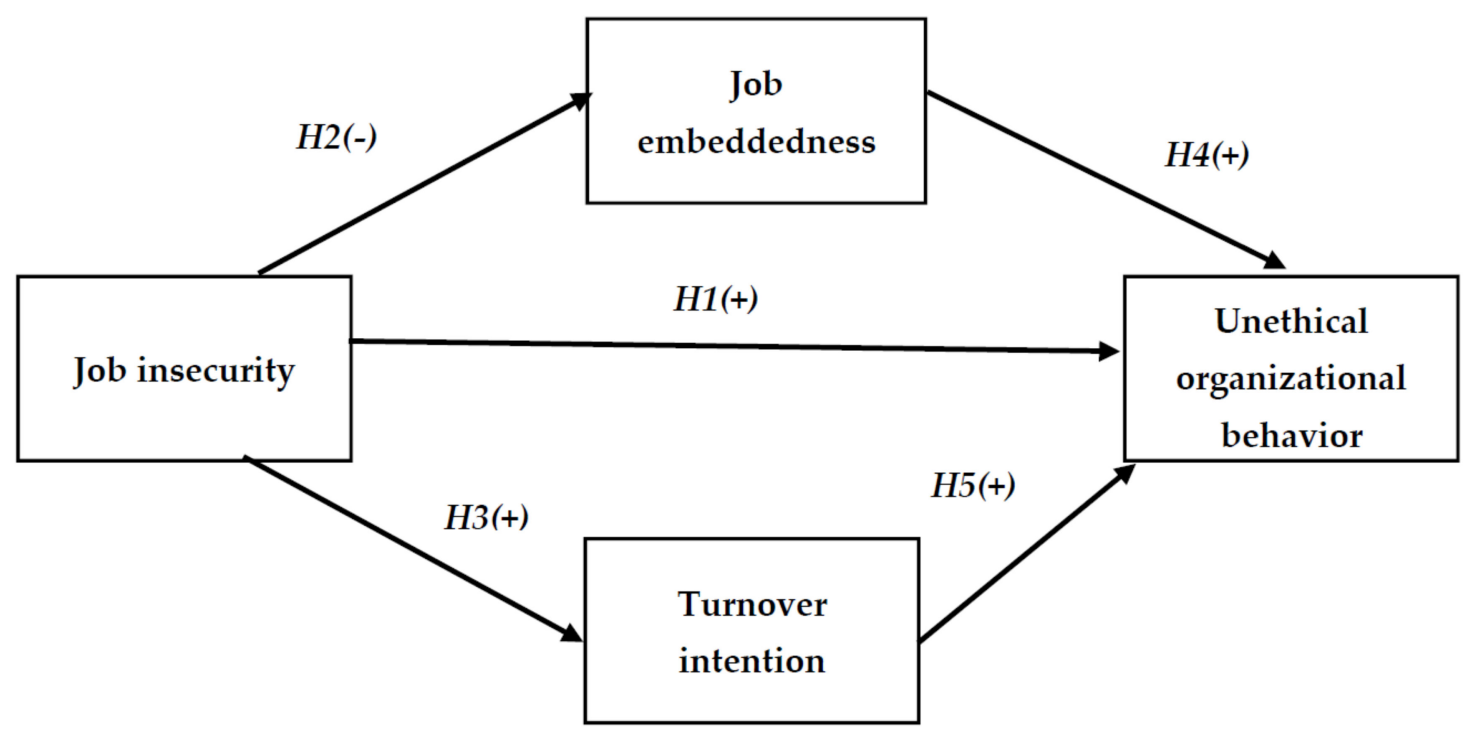

Figure 1. A research framework (developed by authors).

\subsection{Job Insecurity, Job Embeddedness, and Turnover Intention}

When the organization members face and feel job insecurity, threats to financial resources can be devastating. The high risk of losing a job threatens the employees' feelings of embeddedness and fit with the organization. Job embeddedness has been explained as a solid net through which employees at the workplace are attached [31]. The more connections at the workplace that employees have, the more embedded the employee is. The previous literature provides evidence that job insecurity stimulates a lower level of job embeddedness [32].

Employees' feelings of job insecurity will stimulate a search for new job opportunities and increase the possibilities of turnover. The tourism and hospitality industry is one of the industries with the highest employee turnover rates [33], which may be caused by an unstable environment [34]. The worldwide economic crisis initiated by the COVID-19 pandemic certainly altered the perception of regular job insecurity dimensions and brought these to the ultimate level due to the failure to expect the strength and duration of the pandemic [35]. The meta-analytical research conducted by [36] endorses the claim that job insecurity is a major stressor that is directly related to low job satisfaction and high levels of job withdrawal. Notwithstanding, and based on Adams' [37,38] equity theory, employees regularly compare their ratio of inputs and outputs as compared to their peers in the organization, and if an imbalance exists an inequity exists. The authors of [36] argue that employees' feelings of job insecurity could stimulate an imbalanced feeling between their input efforts and output gains. More specifically, employees, compare their organizational 
loyalty with their perceived job security. On the other hand, as employees' feelings of job insecurity increase, their intention to leave the organization will increase [39]. Accordingly, the following hypotheses are proposed.

Hypothesis 2 (H2). Job insecurity has a negative significant impact on job embeddedness.

Hypothesis 3 (H3). Job insecurity has a positive significant impact on turnover intention.

\subsection{Job Embeddedness and Unethical Organizational Behavior}

Job embeddedness defines the affective and cognitive connection with the organization, concerned with the organization-employee fit, and builds the internal and external links in the organization and the sacrifices resulting from the breaking of these links [40]. Therefore, it is defined as a set of 'combined forces' that bind an employee to the job [41,42]. Job embeddedness refers to a person's social involvement within their company [43]. As a result, people who are emotionally attached to their jobs are unlikely to leave the company [40].

Embedded workers are aware of the advantages of being attached to their job. Employees with a high level of job embeddedness feel comfortable and compatible with their coworkers, which leads to heightened levels of attachment to the company [44]. While work embeddedness provides heightened degrees of commitment to the company, it also creates an inherent amount of dependence on the organization in terms of job insecurity [44]. According to self-regulation theory, employees make a conscious effort to match their practices and behaviors with accepted norms [45,46]. Employees with higher levels of embeddedness will demonstrate behaviors that are aligned with the organization as a result of increasing levels of fit and connection. Individuals with low levels of embeddedness, on the other hand, have not developed a strong attachment or fondness for the organization [40]. While work embeddedness increases degrees of attachment to the organization, it also produces an inherent level of dependence on the organization, which contributes to job insecurity [44]. Self-regulation theory argued that employees exert a conscious effort to associate their behaviors with established standards $[45,46]$. Employees who have higher levels of embeddedness will exhibit ethical and/or unethical behaviors in the name of the organization [40]. Therefore, the following hypothesis is proposed:

Hypothesis 4 (H4). Job embeddedness has a positive significant impact on unethical organizational behavior.

\subsection{Turnover Intention and Unethical Organization Behavior}

Employees who are facing turnover intention may participate in unethical organizational behaviors in the hopes that their sacrifices will be rewarded with ongoing employment. However, these unethical behaviors can generate succeeding harms to the organization. On the other hand, employees also may choose to participate in unethical behavior such as padding work hours in an attempt to release some of the disappointment they are suffering regarding the possible job loss [45] and, hence, the following hypothesis is proposed:

Hypothesis 5 (H5). Turnover intention has a positive and significant impact on unethical organizational behavior.

\section{Methodological Approach}

\subsection{Instrument Development and Research Measures}

The current study scales were developed based on a survey of existing theoretical items and a review of the literature. This survey yields four factors, each with its own set of items, which have been customized to fit the tourism sector. The operationalization of the study concepts was derided from previous literature. The study scale was developed using 
a five-point Likert-type scale anchored by ' $1=$ strongly disagree and $5=$ strongly agree', as suggested by $[47,48]$. Similarly, turnover intention (TrnOvr) was measured by three items developed by $[34,49,50]$. Job insecurity (JobInsc) was measured by six quantitative and qualitative items adopted from [51] (e.g., 'I am worried that I will have to leave my job before I would like to'). Job embeddedness (JobEmb) was operationalized by six items developed by [31] (i.e., 'I like the authority and responsibility I have at this company'). Finally, from Umphress et al. [21], seven items to measure unethical organizational behavior were employed (i.e., 'If my organization needed me to, I would give a good recommendation on the behalf of an incompetent employee in the hope that the person will become another organization's problem instead of my own').

The instrument was created in English at first. Back-translation was then conducted [52]. The research instrument was translated from English to Arabic by three academics. In addition, the back translation from Arabic to English was done by a group of two more distinct academics. Both versions were identical. There were no discernible discrepancies between the original and translated instruments. Five academics in the tourism industry, thirty employees, eleven experts, and managers from twenty different hotels were used to validate the research instrument. The pilot respondents provided positive feedback on the consistency, content, and face validity of the scale. The final form of the scale was directed to 700 employees working in five- and four-star hotels in Egypt.

\subsection{Data Collections}

The drop and collect method of distributing and collecting the study questionnaires was employed to ensure a high response rate [53]. Survived employees, who may have an intention to leave the hotel amid the COVID-19 pandemic, were targeted to answer the study instrument. Twenty-five enumerators (faculty students) were instructed to collect data from the respondents in greater Cairo, Hurghada, and Sharm Elsheikh (the biggest tourist cities in Egypt). This method was employed to avert the usual low response rate of mail and/or online approach of data collection and to avert the reluctance to answer the anonymous questionnaires. Enumerators were taught to follow hygiene protocols to minimize the risk of infection for themselves and respondents amid the data collection process during July and August 2021. Respondents were asked to sign a consent form before starting the survey.

With a usable response rate of 97\%, 685 employees working in the Egyptian five- and four-star hotels and travel agent category A participated in the study survey. A total of 65 four-star hotels, 60 five-star hotels, and 60 category A travel agents were represented in the survey. Four/five questionnaires were sent to each hotel/ travel agent to deal with over-or under-representation. The majority (51\%) of the respondents were aged between 31 to 40 and were married $(66 \%)$. The distribution of the respondents according to gender is nearly equivalent, with $55 \%$ male and $45 \%$ female. The majority of respondents were normal employees (85\%), while only $15 \%$ were supervisors. The full-time employees comprised the highest percentage, at $86 \%$, as did employees who had obtained a university degree (85\%). A high percentage (43\%) of respondents have an annual salary below $4000 \$$, as shown in Table 1. 
Table 1. The Demographic characteristics (developed by authors).

\begin{tabular}{|c|c|c|c|c|c|}
\hline $\mathrm{N}=685$ & & $\%$ & Groups & & $\begin{array}{l}\text { Number of } \\
\text { Responses }\end{array}$ \\
\hline Age & & & Five-star Hotels & 65 & 235 \\
\hline $21-30$ & 185 & 27 & Five-star Hotels & 60 & 210 \\
\hline $31-40$ & 350 & 51 & Travel agents & 60 & 240 \\
\hline$>41$ & 150 & 22 & Total & & 685 \\
\hline \multicolumn{6}{|l|}{ Gender } \\
\hline Male & 380 & 55 & & & \\
\hline Female & 305 & 45 & & & \\
\hline \multicolumn{6}{|l|}{ Marital status } \\
\hline Married & 450 & 66 & & & \\
\hline & 235 & 34 & & & \\
\hline Unmarried & 200 & 20 & & & \\
\hline \multicolumn{6}{|l|}{ Occupation } \\
\hline Supervisors & 105 & 15 & & & \\
\hline Normal employees & 580 & 85 & & & \\
\hline \multicolumn{6}{|l|}{ Type of employment } \\
\hline Full time & 590 & 86 & & & \\
\hline Part time & 95 & 14 & & & \\
\hline \multicolumn{6}{|l|}{ Education level } \\
\hline Less than high school & 185 & 27 & & & \\
\hline degree & 200 & 20 & & & \\
\hline High school degree & 100 & 15 & & & \\
\hline University graduate & 400 & 58 & & & \\
\hline \multicolumn{6}{|l|}{ Annual Salary (\$) } \\
\hline Under 4000 & 300 & 43 & & & \\
\hline $4001-6000$ & 150 & 22 & & & \\
\hline $6001-8000$ & 150 & 22 & & & \\
\hline Over 8000 & 85 & 13 & & & \\
\hline
\end{tabular}

\subsection{Non-Response and Common Bias Tests}

Two different methods were employed to deal with the potential non-response bias: univariate analysis 'independent samples $t$-test, analysis of the variance (ANOVA) and multivariate analysis 'multivariate analysis of the variance (MANOVA). The findings of the two tests did not statistically generate any significant discrepancies at a 95\% confidence level for early and late respondents [54]. To test the potential common method variance, Harmon's one-factor test method, as suggested by [55], was conducted. The one factor extracted solution accounts for $25 \%$ of the variance, which gives evidence that no one factor accounted for the majority of the variance, implying that common method variance is not fully responsible for our findings.

Questionnaire items had a maximum and minimum value of 5 and 1, respectively. The mean scores for all answers ranged from 3.31 to 4.08 , with standard deviation values ranging from 1.230 to 0.603 (see Table 2), indicating that the study data is more dispersed and less condensed around the mean value [56]. Furthermore, the skewness and kurtosis values in Table 2 indicated that the data did not violate the normality rules [57]. 
Table 2. Descriptive statistics (developed by authors based on previous literature).

\begin{tabular}{|c|c|c|c|c|c|c|c|}
\hline Abbr. & Items & Min & Max & $\mathbf{M}$ & S.D & Skewness & Kurtosis \\
\hline \multicolumn{8}{|c|}{ Job Insecurity } \\
\hline JobInsc_1 & $\begin{array}{c}\text { "I am worried that I will have to leave my } \\
\text { job before I would like to". }\end{array}$ & 1 & 5 & 3.33 & 1.086 & -0.353 & -0.422 \\
\hline JobInsc_2 & "I worry about being able to keep my job". & 1 & 5 & 3.33 & 1.101 & -0.328 & -0.489 \\
\hline JobInsc_3 & "I am afraid I may lose my job shortly". & 1 & 5 & 3.36 & 1.060 & -0.343 & -0.385 \\
\hline JobInsc_4 & $\begin{array}{l}\text { "I worry about getting less stimulating work } \\
\text { tasks in the future". }\end{array}$ & 1 & 5 & 3.31 & 1.127 & -0.399 & -0.364 \\
\hline JobInsc_5 & $\begin{array}{l}\text { "I worry about my future wage } \\
\text { development". }\end{array}$ & 1 & 5 & 3.31 & 1.123 & -0.404 & -0.344 \\
\hline JobInsc_6 & $\begin{array}{l}\text { "I feel worried about my career } \\
\text { development in the organization". }\end{array}$ & 1 & 5 & 3.31 & 1.140 & -0.432 & -0.328 \\
\hline \multicolumn{8}{|c|}{ Job Embeddedness } \\
\hline JobEmb_1 & "I like the members of my workgroup". & 1 & 5 & 3.57 & 1.220 & -0.394 & -0.953 \\
\hline JobEmb_2 & “My coworkers are similar to me". & 1 & 5 & 3.54 & 1.169 & -0.334 & -0.918 \\
\hline JobEmb_3 & "My job utilizes my skills and talents well". & 1 & 5 & 3.59 & 1.162 & -0.328 & -0.957 \\
\hline JobEmb_4 & $\begin{array}{l}\text { "I feel like I am a good match for this } \\
\text { company". }\end{array}$ & 1 & 5 & 3.47 & 1.191 & -0.324 & -0.938 \\
\hline JobEmb_5 & "I fit with the company's culture". & 1 & 5 & 3.51 & 1.184 & -0.346 & -0.904 \\
\hline JobEmb_6 & $\begin{array}{l}\text { "I like the authority and responsibility I } \\
\text { have at this company". }\end{array}$ & 1 & 5 & 3.62 & 1.184 & -0.396 & -0.953 \\
\hline \multicolumn{8}{|c|}{ Turnover Intention } \\
\hline trnOvr_1 & "I often think about leaving that career". & 1 & 5 & 4.08 & .618 & -1.439 & 1.485 \\
\hline trnOvr_2 & $\begin{array}{l}\text { "It would not take much to make me leave } \\
\text { this career". }\end{array}$ & 1 & 5 & 4.07 & .629 & -1.463 & 1.198 \\
\hline trnOvr_3 & $\begin{array}{l}\text { "I will probably be looking for another } \\
\text { career soon". }\end{array}$ & 1 & 5 & 4.08 & .603 & -1.439 & 1.993 \\
\hline \multicolumn{8}{|c|}{ Unethical Organizational Behavior } \\
\hline Unethic_1 & $\begin{array}{l}\text { "If it would help my organization, I would } \\
\text { misrepresent the truth to make my } \\
\text { organization look good". }\end{array}$ & 1 & 5 & 3.85 & 1.203 & -1.073 & 0.275 \\
\hline Unethic_2 & $\begin{array}{c}\text { "If it would help my organization, I would } \\
\text { exaggerate the truth about my "company's } \\
\text { products or services to customers and } \\
\text { clients"." }\end{array}$ & 1 & 5 & 3.76 & 1.230 & -0.974 & -0.020 \\
\hline Unethic_3 & $\begin{array}{l}\text { "If it would benefit my organization, I } \\
\text { would withhold negative information about } \\
\text { my company or its products from customers } \\
\text { and clients". }\end{array}$ & 1 & 5 & 3.80 & 1.208 & -1.016 & 0.171 \\
\hline Unethic_4 & $\begin{array}{l}\text { "If my organization needed me to, I would } \\
\text { give a good recommendation on the behalf } \\
\text { of an incompetent employee in the hope that } \\
\text { the person will become another } \\
\text { organization's problem instead of my own". }\end{array}$ & 1 & 5 & 3.79 & 1.224 & -1.031 & 0.140 \\
\hline Unethic_5 & $\begin{array}{l}\text { "If my organization needed me to, I would } \\
\text { withhold issuing a refund to a customer or } \\
\text { client accidentally overcharged". }\end{array}$ & 1 & 5 & 3.76 & 1.222 & -0.963 & 0.031 \\
\hline Unethic_6 & $\begin{array}{l}\text { "If needed, I would conceal information } \\
\text { from the public that could be damaging to } \\
\text { my organization". }\end{array}$ & 1 & 5 & 3.75 & 1.250 & -0.981 & -0.013 \\
\hline Unethic_7 & $\begin{array}{c}\text { "I would do whatever it takes to help my } \\
\text { organization". }\end{array}$ & 1 & 5 & 3.74 & 1.245 & -0.945 & -0.085 \\
\hline
\end{tabular}




\section{Results}

\subsection{Confirmatory Factor Analysis}

Confirmatory factor analysis (CFA) was employed to evaluate the overall model fit with the data and to determine the unidimensionality of the study constructs. Several researchers recommended that $(\chi 2 / \mathrm{df})$ should be less than 3 and that all fit indices, such as Comparative Fit Index (CFI) and Tucker-Lewis Index (TLI), should be greater than 0.9, while root-mean-square error of approximation (RMSEA) and root-mean-square residual (RMR) should be less than 0.08 [57-59]. To assess the factors' reliability and validity, Analysis of Moment Structures (AMOS) v25 was employed to test a first-order confirmatory factor analysis with all of the study's dependent and independent variables. The result of our CFA model in Table 3 revealed that the overall fit statistics indicate a satisfactory model fit, as all obtained fit statistics met the recommended cut-off values.

Convergent and discriminant validity for each construct were evaluated to determine the construct validity. Table 3 showed that factor loadings for all study constructs' items are all significant at the 0.001 level, exceeding the minimum criteria of 0.5 . Furthermore, all of the research constructs had AVEs greater than 0.5 , and the construct reliability values for all four constructs exceed the 0.70 criterion. Overall, the previous results showed good convergent validity, as recommended by $[60,61]$

Table 3. Convergent and discriminant validity (developed by authors).

\begin{tabular}{|c|c|c|c|c|c|c|c|c|}
\hline Dimensions and Items & Loading & CR & AVE & MSV & 1 & 2 & 3 & 4 \\
\hline \multicolumn{2}{|c|}{ 1-Job Insecurity $(a=0.965)$} & 0.9590 & 0.7970 & 0.0210 & 0.8930 & & & \\
\hline JobInsc_1 & 0.934 & & & & & & & \\
\hline JobInsc_2 & 0.965 & & & & & & & \\
\hline JobInsc_3 & 0.962 & & & & & & & \\
\hline JobInsc_4 & 0.836 & & & & & & & \\
\hline JobInsc_5 & 0.829 & & & & & & & \\
\hline JobInsc_6 & 0.818 & & & & & & & \\
\hline \multicolumn{2}{|c|}{-2-Job Embeddedness $(a=0.981)$} & 0.9820 & 0.8990 & 0.003 & -0.055 & 0.9480 & & \\
\hline JobEmb_1 & 0.948 & & & & & & & \\
\hline JobEmb_2 & 0.974 & & & & & & & \\
\hline JobEmb_3 & 0.958 & & & & & & & \\
\hline JobEmb_4 & 0.913 & & & & & & & \\
\hline JobEmb_5 & 0.952 & & & & & & & \\
\hline JobEmb_6 & 0.943 & & & & & & & \\
\hline \multicolumn{2}{|c|}{ 3-Turnover Intention $(a=0.918)$} & 0.9180 & 0.7890 & 0.0210 & 0.1440 & 0.0230 & 0.888 & \\
\hline trnOvr_1 & 0.887 & & & & & & & \\
\hline trnOvr_2 & 0.916 & & & & & & & \\
\hline trnOvr_3 & 0.861 & & & & & & & \\
\hline \multicolumn{2}{|c|}{ 4-Unethical Organizational Behavior $(a=0.978)$} & 0.9770 & 0.8590 & 0.0130 & -0.116 & -0.040 & 0.0370 & 0.927 \\
\hline Unethic_1 & 0.916 & & & & & & & \\
\hline Unethic_2 & 0.885 & & & & & & & \\
\hline Unethic_3 & 0.936 & & & & & & & \\
\hline Unethic_4 & 0.916 & & & & & & & \\
\hline Unethic_5 & 0.975 & & & & & & & \\
\hline Unethic_6 & 0.968 & & & & & & & \\
\hline Unethic_7 & 0.886 & & & & & & & \\
\hline
\end{tabular}

Model fit: $(\chi 2(203, \mathrm{~N}=685)=585.046, p<0.001$, normed $\chi 2=2.882$, RMSEA $=0.049$, SRMR $=0.050, \mathrm{CFI}=0.937$ $\mathrm{TLI}=0.924, \mathrm{NFI}=0.938, \mathrm{PCFI}=0.797$ and PNFI $=0.816) . \mathrm{CR}$ : composite reliability; AVE: average variance extracted; MSV: maximum shared value; Diagonal values: the square root of AVE for each dimension; Below diagonal values: intercorrelation between dimensions.

Cronbach alpha values, correlation matrix, and the square root of AVEs were utilized to test the discriminant validity [62]. Table 3 shows the average variance extracted (AVE), correlation matrix, and composite Cronbach alphas for the research variables. As shown in Table 3, the square root of AVEs was higher than the off-diagonal values, which represent the correlations among those constructs, confirming discriminant validity for research factors as 
suggested by [62]. Moreover, the average variance extracted (AVE) scores for job insecurity (0.797), job embeddedness (0.899), turnover intention (0.789), and unethical organizational behavior (0.859) exceeded the maximum shared variance (MSV) (ranging from 0.021 to 003), further confirmed that the discriminant validity is supported, as suggested by $[59,62]$. Additionally, for discriminant validity, the inter-correlations scores for each factor (below diagonal value) should not surpass the square root values of the AVE for each factor (bold diagonal) as shown in Table 3, which further support the discriminant validity of the research variables.

\subsection{Structural Equations Modeling (SEM) Results}

After ensuring that the validity and reliability of the measures were adequate, structural equation modeling was employed to test the impact of job insecurity on unethical organizational behavior via job embeddedness and turnover intention. Two criteria are employed to assess the proposed model: overall goodness of model fit " $\chi 2 / \mathrm{df}, \mathrm{CFI}$, TLI. RMSEA, and RMR" and the statistical significance of the hypothesized relationships. The overall model fit values for the structural model demonstrated satisfactory values, as displayed in Table 4. Moreover, Figure 2 and Table 4 explain the proposed model output.

The relationships in the proposed model involving the five hypotheses investigate the impact of job insecurity on unethical organizational behavior via job embeddedness and turnover intention. The results show that the four paths ( $\mathrm{H} 1, \mathrm{H} 3, \mathrm{H} 4$, and $\mathrm{H} 5)$ are positive and significant with $p<0.05$, whereas one path was negative but significant $(\mathrm{H} 2)$. The significant positive effect of job insecurity on unethical organizational behavior had been supported $(\beta 1=+0.29$ with $\mathrm{t}$-value $=6.320, p<0.001)$. Nevertheless, job insecurity has a significant but negative link with job embeddedness that supports $\mathrm{H} 2(\beta 2=-0.36$ with $\mathrm{t}$-value $=-9.448, p<0.001)$. The model findings also demonstrate that job insecurity significantly and positively impacts turnover intention $(\beta 3=+0.41$ with $\mathrm{t}$-value $=10.221$, $p<0.001)$ that proves H3. As assumed in H4, job embeddedness has a positive and significant effect on unethical organizational behavior $(\beta 4=+0.47$ with $\mathrm{t}$-value $=11.116$, $p<0.001)$ that endorses H4. Similarly, turnover intention was found to have a positive significant impact on unethical organizational behavior, which supports $\mathrm{H} 5(\beta 5=+0.32$ with t-value $=7.252, p>0.001)$.

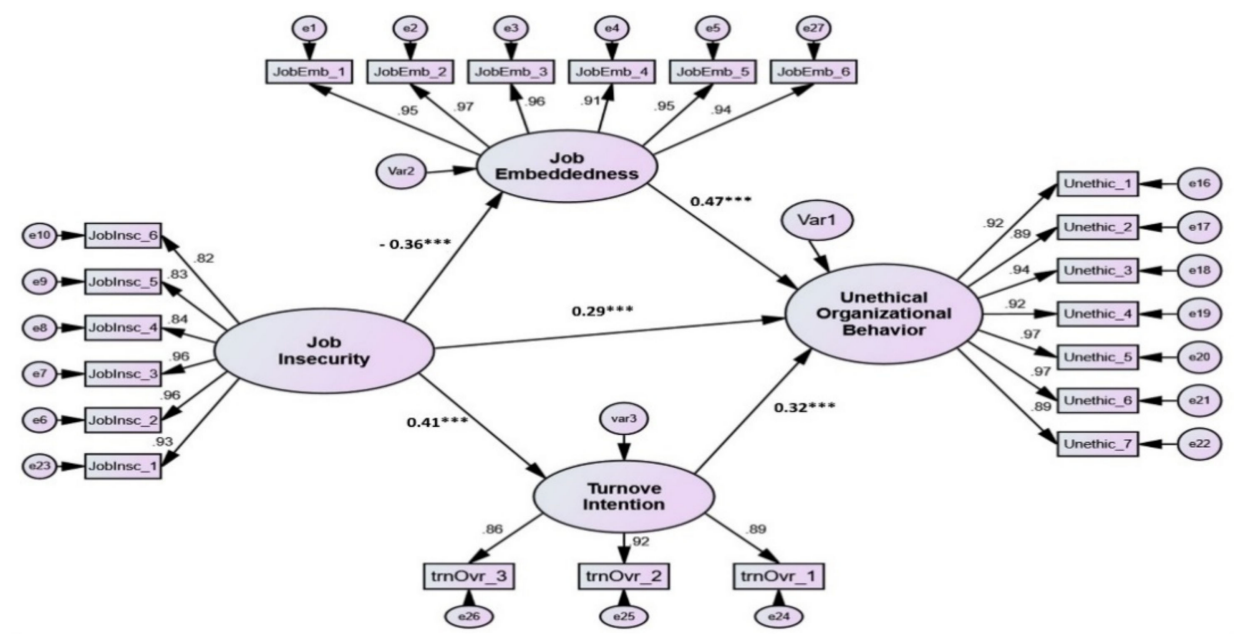

Figure 2. Research model (developed by authors). ${ }^{* * *}$ Significant level is less than 0.001 . 
Table 4. Result of the structural model (developed by authors).

\begin{tabular}{|c|c|c|c|c|c|c|}
\hline & & ypotheses & $\begin{array}{c}\text { Beta } \\
(\beta)\end{array}$ & $\begin{array}{c}\text { C-R } \\
\text { (T-Value) }\end{array}$ & $\mathbf{R}^{2}$ & $\begin{array}{c}\text { Hypotheses } \\
\text { Results }\end{array}$ \\
\hline H1 & Job Insecurity & Unethical organizational behavior & $0.29 * * *$ & 6.320 & & Supported \\
\hline $\mathrm{H} 2$ & Job Insecurity & Job embeddedness & $-0.36^{* * *}$ & -9.448 & & Supported \\
\hline H3 & Job Insecurity & Turnover intention & $0.41 * * *$ & 10.221 & & Supported \\
\hline $\mathrm{H} 4$ & Job embeddedness & Unethical organizational behavior & $0.47^{* * *}$ & 11.116 & & Supported \\
\hline H5 & Turnover intention & Unethical organizational behavior & $0.32 * * *$ & 7.252 & & Supported \\
\hline \multicolumn{3}{|c|}{ Unethical organizational behavior } & & & 0.42 & \\
\hline
\end{tabular}

Model fit: $\left(\chi^{2}(204, \mathrm{~N}=685)=612.204, p<0.001\right.$, normed $\chi^{2}=3.001, \mathrm{RMSEA}=0.050, \mathrm{SRMR}=0.051, \mathrm{CFI}=0.924$ $\mathrm{TLI}=0.927, \mathrm{NFI}=0.929, \mathrm{PCFI}=0.719$ and PNFI $=0.706) .{ }^{* * *} p<0.00, \mathrm{n} / \mathrm{s}=$ not significant.

The power of the tested structural model is further proven by the significant coefficient of determination (R2) value of 0.42 percent of the variance in unethical organizational behavior can be explained through job insecurity, job embeddedness, and turnover intention.

Additionally, besides the previous direct relationships, the Amos output can provide further information about the indirect effects that can be employed to test the mediation effects in the tested model. To investigate the mediation of job embeddedness and turnover intention in the relationship between job insecurity and unethical organizational behavior, the recommendations of $[63,64]$ were adopted. According to Zhao et al. [64], for a directonly non-mediation impact, only a direct relationship must exist and be significant; for complementary mediation, both direct and indirect effects must exist and be significant with the same signs. Finally, if both direct and indirect effects are significant with opposite signs, competitive mediation is obtained.

Accordingly, as pictured in Figure 2 and displayed in Table 4, the direct path from job insecurity to turnover intention is positive and significant $(\beta=+0.29, p<0.001)$; and turnover intention positively and significantly affects unethical organizational behavior $(\beta=+0.32, p>0.001)$, hence complementary mediation is supported for the mediation effect of turnover intention in the relationship between job insecurity and unethical organizational behavior. On the other hand, the direct path from job insecurity to job embeddedness is negative but significant $(\beta=-0.36, p<0.001)$; and job embeddedness positively and significantly affects unethical organizational behavior $(\beta=+0.47, p>0.001)$; hence, competitive mediation is supported for the mediation effect of job embeddedness in the relationship between job insecurity and unethical organizational behavior.

\section{Discussion and Contributions}

The COVID-19 pandemic has spread across multiple countries at the same time and has harmed numerous industries, including the hospitality industry. Multiple approaches have been used to flatten the COVID-19 curve, including lockdowns, social distancing measures, quarantine at home, and travel restrictions, resulting in the temporary closure of many hospitality organizations [65]. Accordingly, hospitality businesses have reacted to the massive losses experienced amid the pandemic by laying off most of their employees. Because employees in developing countries (i.e., Egypt) may be more exposed to job insecurity as a result of inadequate employment protection laws or poor economic environments [66,67], the current study has an exceptional context by testing the impacts of job insecurity on unethical organization behavior among hospitality employees (hotels and travel agents) in a developing country (i.e., Egypt) amid the COVID-19 pandemic.

This paper has attempted to explore and understand the psychological process through which unethical behaviors and decisions are conducted by employees who encountered job insecurity. A total of 650 employees working in the hotel industry and travel agent companies were surveyed to better explain and predict in what way and under what circumstances employees faced with potential job loss amid the COVID-19 pandemic are prone to participate in unethical behaviors. Job embeddedness and turnover intention were employed as mediating variables.

Consistent with the expectations and previous studies' results [68-74], job insecurity was found to reduce job embeddedness, reinforce the turnover intention, and promote em- 
ployees' unethical organizational behavior. However, there are scarce studies conducted in non-Western countries on these relationships [75]. Consequently, this research contributed to the literature by studying these relationships in the Egyptian context. Scholars have found that employees overcome the perception of job insecurity by working hard, seeking help from others [34,76], and engaging in impression management [77]. However, there is scarce research that examines employees' reactions to job insecurity by practicing behaviors that are unethical but are in the name of the company.

Job insecurity was found to directly increase employees' unethical behavior in the name of the company. Employees may practice unethical organizational behavior that may, in turn, assist them to be perceived as valuable to the organization and, accordingly, retain employment or employment benefits. This result is consistent with [21], in which it was found that job insecurity promotes employees' unethical behavior.

Following $[74,78]$, job insecurity was found to have a negative impact on employee embeddedness to the organizations, especially amid the COVID-19 pandemic. When employees feel the risk of future job loss and insecurity, they begin to reconsider their job and their future career path in the company [32]. This causes them to lose association with their supervisors and destruction in the match and alignment between their beliefs and values and those of the organization. Due to a lack of empirical study on the factors that influence job embeddedness [79], this result can enhance our understanding of such a relationship. Job embeddedness, in turn, was found to promote employees' unethical behavior in the name of the company. This result is consistent with [31], who argued that, as a result of increased levels of alignment and attachment between the employees and the company, employees with higher levels of embeddedness will exhibit unethical behaviors in the name of the organization.

Additionally, the current study gives evidence that when employees feel insecure, their turnover intention is increased. This result is consistent with the study by [80]. Furthermore, several previous studies have shown that job insecurity impacts job dissatisfaction and intention to quit the job $[81,82]$. Turnover intention, in turn, can increase the employees' unethical behaviors in the name of the company in the hopes that their sacrifices will be rewarded with ongoing employment.

This study provides two contributions to practitioners and academics. First, job insecurity should be a high priority for top-level management and human resource managers in hospitality organizations because it leads to a variety of negative consequences not only for employees but for the organization as well. These consequences can include reduced job embeddedness, low job satisfaction, reduced trust in management, poor organizational performance, increases in unethical organizational behavior, and high turnover intention. The study, as well, highlighted the mediating role of job embeddedness and turnover intention in increasing the effect of job insecurity on unethical organizational behavior, as the direct impact of job insecurity on unethical organizational behavior was further strengthened through these two mediators. Testing these relationships may enhance academic's understanding of the nature of the relationships between job insecurity and unethical behavior.

Second, the study has further implications for managers in the hospitality industry. In the context of a developing country (e.g., Egypt), where unemployment levels are substantially high [8], job insecurity amid the pandemic may have destructive outcomes for hospitality businesses. Perceived job insecurity may threaten the reputation and goodwill of the hospitality industry due to employee's practicing unethical behavior in the name of the company to retain employment or employment benefits. Consequently, amid such a severe pandemic, managers in the hospitality industry should avoid sending out signals that may cause their employees to believe that they are in danger of losing their jobs. Any uncertainty or miscommunication on the side of management can lead to workers' feelings of insecurity, resulting in low job embeddedness and high turnover intention, and can promote unethical behavior in the name of the company. 


\section{Study Limitations and Directions for Future Research}

This study has four limitations. First, job embeddedness and turnover intention were found to be partially mediated by the impact of job insecurity on unethical organizational behavior. However, other variables (e.g., justice, job satisfaction, and trust in supervisor,) may also intervene in this relationship. As a result, future studies should look at whether the impacts are direct or are mediated by factors other than job embeddedness and turnover intention. Second, due to the cross-sectional nature of the data obtained, causal correlations among the variables cannot be deduced. Third, although we attempted to avoid common technique bias [36], future researchers could employ longitudinal data or a variety of data sources. Fourth, a different model can be employed to test these relationships in different contexts using a multi-group analysis technique [83].

Author Contributions: Conceptualization, I.A.E. and A.M.S.A.; methodology, I.A.E. and A.M.S.A.; software, I.A.E.; validation, I.A.E. and A.M.S.A.; formal analysis, I.A.E. and A.M.S.A.; investigation, I.A.E. and A.M.S.A.; resources, I.A.E.; data curation, I.A.E.; writing-original draft preparation, I.A.E., and A.M.S.A.; writing-review and editing, I.A.E. and A.M.S.A.; visualization, I.A.E.; supervision, I.A.E.; project administration, I.A.E. and A.M.S.A.; funding acquisition, I.A.E. and A.M.S.A. All authors have read and agreed to the published version of the manuscript.

Funding: The authors acknowledge the Deanship of Scientific Research at King Faisal University for the financial support under Nasher Track (Grant No. NA000163).

Institutional Review Board Statement: The study was conducted according to the guidelines of the Declaration of Helsinki and approved by the deanship of scientific research ethical committee, King Faisal University (project number: NA000163, date of approval: 1 October 2021).

Informed Consent Statement: Informed consent was obtained from all subjects involved in the study.

Data Availability Statement: Data is available upon request from researchers who meet the eligibility criteria. Kindly contact the first author privately through e-mail.

Conflicts of Interest: The authors declare no conflict of interest.

\section{References}

1. International Labor Organization. ILO: As job losses escalate, nearly half of global workforce at risk of losing livelihoods; International Labour Organization, 2020. Available online: https://www.ilo.org/global/about-the-ilo/newsroom/news/WCMS_743036 /lang--en/index.htm (accessed on 30 April 2019).

2. Jones, L.; Palumbo, D.; Brown, D. Coronavirus: A Visual Guide to the Economic Impact. BBC News. 2020. Available online: https: //www.unic.ac.cy/da/2020/05/08/coronavirus-a-visual-guide-to-the-economic-impact-bbc-news/ (accessed on 3 December 2020).

3. Frank, T. Hardest-Hit Industries: Nearly Half the Leisure and Hospitality Jobs were Lost in April; CNBC, 2020. Available online: https://www.cnbc.com/2020/05/08/1 (accessed on 30 April 2019).

4. Calderwood, L.U.; Soshkin, M. The Travel E Tourism Competitiveness Report 2019. Travel and Tourism at a Tipping Point; World Economic Forum: Geneva, Switzerland, 2019. Available online: https://apo.org.au/node/257631 (accessed on 30 April 2019).

5. Rivera, M. Hitting the reset button for hospitality research in times of crisis: COVID-19 and beyond. Int. J. Hosp. Manag. 2020, 87, 102528. [CrossRef] [PubMed]

6. Karmin, C. Marriott begins furloughing tens of thousands of employees. Wall Str. J. 2020. Available online: https://www.wsj.com/ articles/marriott-starting-to-furlough-tens-of-thousands-of-employees-11584459417 (accessed on 30 April 2019).

7. Kelly, J. Airbnb lays off $25 \%$ of its employees: CEO brian chesky gives a master class in empathy and compassion. Forbes 2020. Available online: https:/ / www.forbes.com/sites/jackkelly/2020/05/06/airbnb-lays-off-25-of-its-employees-ceo-brian-cheskygives-a-master-class-in-empathy-and-compassion/ (accessed on 30 April 2019).

8. Saad, S.K.; Elshaer, I.A. Justice and trust's role in employees "resilience and business" continuity: Evidence from Egypt. Tour. Manag. Perspect. 2020, 35, 100712. [CrossRef]

9. Cheng, G.H.L.; Chan, D.K.S. Who suffers more from job insecurity? A meta-analytic review. Appl. Psychol. 2008, 57, 272-303. [CrossRef]

10. Jung, H.S.; Jung, Y.S.; Yoon, H.H. COVID-19: The effects of job insecurity on the job engagement and turnover intent of deluxe hotel employees and the moderating role of generational characteristics. Int. J. Hosp. Manag. 2021, 92, 102703. [CrossRef] [PubMed]

11. Darvishmotevali, M.; Arasli, H.; Kilic, H. Effect of job insecurity on frontline employee's performance. Int. J. Contemp. Hosp. Manag. 2017, 29, 1724-1744. [CrossRef] 
12. Etehadi, B.; Karatepe, O.M. The impact of job insecurity on critical hotel employee outcomes: The mediating role of self-efficacy. J. Hosp. Mark. Manag. 2019, 28, 665-689. [CrossRef]

13. Shin, Y.; Hur, W.M. When do service employees suffer more from job insecurity? The moderating role of coworker and customer incivility. Int. J. Environ. Res. Public Health 2019, 16, 1298. [CrossRef]

14. Akgunduz, Y.; Eryilmaz, G. Does turnover intention mediate the effects of job insecurity and co-worker support on social loafing? Int. J. Hosp. Manag. 2018, 68, 41-49. [CrossRef]

15. Boswell, W.R.; Olson-Buchanan, J.B.; Harris, T.B. I cannot afford to have a life: Employee adaptation to feeling of job insecurity. Pers. Psychol. 2014, 67, 887-915. [CrossRef]

16. Yi, X.; Wang, S. Revisiting the curvilinear relation between job insecurity and work withdrawal: The moderating role of achievement orientation and risk aversion. Hum. Resour. Manag. 2015, 54, 499-515. [CrossRef]

17. Hirsch, P.M.; De Soucey, M. Organizational restructuring and its consequences: Rhetorical and structural. Annu. Rev. Sociol. 2006, 32, 171-189. [CrossRef]

18. Burchell, B. The prevalence and redistribution of job insecurity and work intensification. In Job Insecurity and Work Intensification; Burchell, B., Ladipo, D., Wilkinson, F., Eds.; Routledge: London, UK, 2002; pp. 61-76.

19. Debus, M.E.; Probst, T.M.; Konig, C.J.; Kleinmann, M. Catch me if I fall! Enacted uncertainty avoidance and the social safety net as country-level moderators in the job insecurity-job attitudes link. J. Appl. Psychol. 2012, 97, 690-698. [CrossRef]

20. Keim, A.C.; Landis, R.S.; Pierce, C.A.; Earnest, D.R. Why do employees worry about their job? A meta-analytical review of predictors of job insecurity. J. Occup. Health Psychol. 2014, 19, 269-290.

21. Umphress, E.E.; Bingham, J.B.; Mitchell, M.S. Unethical behavior in the name of the company: The moderating effect of organizational identification and positive reciprocity beliefs on unethical pro-organizational behavior. J. Appl. Psychol. 2010, 95, 769. [CrossRef]

22. Greenhalgh, L.; Rosenblatt, Z. Evolution of research on job insecurity. Int. Stud. Manag. Organ. 2010, 40, 6-19. [CrossRef]

23. Tu, Y.; Long, L.; Wang, H.J.; Jiang, L. To prevent or to promote: How regulatory focus moderates the differentiated effects of quantitative versus qualitative job insecurity on employee stress and motivation. Int. J. Stress Manag. 2020, 27, 1-135. [CrossRef]

24. Martin, K.D.; Cullen, J. Continuities and extensions of ethical climate theory: A meta-analytic review. J. Bus. Ethics 2006, 69, 175-194. [CrossRef]

25. Frone, M.R. What happened to the employed during the Great Recession? A US population study of net change in employee insecurity, health, and organizational commitment. J. Vocat. Behav. 2018, 107, 246-260. [CrossRef]

26. Meyer, J.P.; Allen, N.J. Testing the 'side-bet theory' of organizational commitment: Some methodological considerations. J. Appl. Psychol. 1984, 69, 372-378. [CrossRef]

27. Niesen, W.; Hootegem, A.V.; Handaja, Y.; Battistelli, A.; De Witte, H. Quantitative and qualitative job insecurity and idea generation: The mediating role of psychological contract breach. Scan. J. Work. Organ. Psychol. 2018, 3, 1-14. [CrossRef]

28. Vohs, K.D.; Schmeichel, B.J. Self-regulation and extended now: Controlling the self-alters the subjective experience of time. J. Pers. Soc. Psychol. 2003, 85, 217. [CrossRef] [PubMed]

29. Baumeister, R.F. Esteem threat, self-regulatory breakdown, and emotional distress. Rev. Gen. Psychol. 1997, 2, 145-174. [CrossRef]

30. Baumeister, R.F. Ego depletion, the executive function, and self-control: An energy model of the self in personality. In Personality Psychology in the Workplace: Decade of Behavior: 299-316; Roberts, B.W., Hogan, R., Eds.; American Psychological Association: Washington, DC, USA, 2001.

31. Mitchell, T.R.; Holtom, B.C.; Lee, T.W.; Sablynski, C.J.; Erez, M. Why people stay: Using job embeddedness to predict voluntary turnover. Acad. Manage. J. 2001, 44, 1102-1121.

32. Murphy, W.M.; Burton, J.P.; Henagan, S.C.; Briscoe, J.P. Employee reactions to job insecurity in a declining economy: A longitudinal study of the mediating role of job embeddedness. Group. Organ. Manag. 2013, 38, 512-537. [CrossRef]

33. Gok, O.A.; Akgunduz, Y.; Alkan, C. The effects of job stress and perceived organizational support on turnover intentions of hotel employees Ozge. J. Tour. 2012, 3, 23-32.

34. Elshaer, I.A.; Saad, S.K. Political instability and tourism in Egypt: Exploring survivors' attitudes after downsizing. J. Policy Res. Tour. Leis. Events 2017, 9, 3-22.

35. Bajrami, D.D.; Terzić, A.; Petrović, M.D.; Radovanović, M.; Tretiakova, T.N.; Hadoud, A. Will we have the same employees in hospitality after all? The impact of COVID-19 on employees' work attitudes and turnover intentions. Int. J. Hosp. Manag. 2021, 94, 102754.

36. Podsakoff, N.P.; LePine, J.A.; LePine, M.A. Differential challenge stressor-hindrance stressor relationships with job attitudes, turnover intentions, turnover, and withdrawal behavior: A meta-analysis. J. Appl. Psychol. 2007, 92, 438-454. [CrossRef]

37. Adams, J.S. Toward an understanding of inequity. J. Abnorm. Soc. Psychol. 1963, 67, 422-436. [CrossRef]

38. Adams, J.S. Inequity in social exchange. In Advances in Experimental Social Psychology; Berkowitz, L., Ed.; Academic Press: Cambridge, MA, USA, 1965; Volume 2, pp. 267-299.

39. Hanafiah, M. Pengaruh kepuasan kerja dan ketidakamanan kerja (job insecurity) dengan intensi pindah kerja (turnover) pada karyawan PT. J. Psikol. 2014, 1, 303-312.

40. Yaqub, R.M.S.; Mahmood, S.; Hussain, N.; Sohail, H.A. Ethical leadership and turnover intention: A moderated mediation model of job embeddedness and organizational commitment. Bull. Bus. Econ. 2021, 10, 16-34. 
41. Crossley, C.D.; Bennett, R.J.; Jex, S.M.; Burnfield, J.L. Development of a global measure of job embeddedness and integration io a traditional model of voluntary turnover. J. Appl. Psychol. 2007, 92, 1031-1042. [CrossRef] [PubMed]

42. Yao, T.; Qiu, Q.; Wei, Y. Retaining hotel employees as internal customers: Effect of organizational commitment on attitudinal and behavioral loyalty of employees. Int. J. Hosp. Manag. 2019, 76, 1-8. [CrossRef]

43. Holtom, B.C.; Inderrieden, E.J. Integrating the unfolding model and job embeddedness model to better understand voluntary turnover. J. Manag. 2006, 18, 435-452.

44. Eberly, M.; Holtmon, B.; Lee, T.; Mitchell, T. Control voluntary turnover by understanding its causes. In Handbook of Principles of Organizational Behavior; Locke, E.A., Ed.; John Wiley \& Sons: New York, NY, USA, 2009.

45. Baumeister, R.F. The self. In Handbook of Social Psychology, 4th ed.; Gilbert, D.T., Fiske, S.T., Lindzey, G., Eds.; McGraw-Hill: New York, NY, USA, 1998; pp. 680-740.

46. Baumeister, R.F.; Bushman, B.J. Social Psychology and Human Nature, 2nd ed.; Wadsworth: Belmont, CA, USA, 2010.

47. Maddox, R.N. Measuring satisfaction with tourism. J. Travel. Res. 1985, 23, 2-5. [CrossRef]

48. Churchill, G.A., Jr. A paradigm for developing better measures of marketing constructs. J. Mark. Res. 1979, 16, 64-73. [CrossRef]

49. Karatepe, O. An investigation of the joint effects of organizational tenure and supervisor support on work-family conflict and turnover intentions. J. Hosp. Tour. Manag. 2009, 16, 73-81. [CrossRef]

50. Singh, J.; Verbeke, W.; Rhoads, G.K. Do Organizational Practices Matter in Role Stress Processes? A Study of Direct and Moderating Effects for Marketing-Oriented Boundary Spanners. J. Mark. 1996, 60, 69-86. [CrossRef]

51. Hellgren, J.; Sverke, M.; Isaksson, K. A two-dimensional approach to job insecurity: Consequences for employee attitudes and well-being. Eur. J. Work. Organ. Psychol. 1999, 8, 179-195. [CrossRef]

52. Douglas, S.P.; Craig, C.S. Collaborative and iterative translation: An alternative approach to back translation. J. Int. Mark. 2007, 15, 30-43. [CrossRef]

53. Ibeh, K.; Brock, J.K.U.; Zhou, Y.J. The drop and collect survey among industrial populations: Theory and empirical evidence. Ind. Mark. Manag. 2004, 33, 155-165. [CrossRef]

54. Armstrong, J.S.; Overton, T. Estimating nonresponse bias in mail surveys. J. Mark. Res. 1977, 14, 396-402. [CrossRef]

55. Podsakoff, P.M.; Organ, D.W. Self-reports in organizational research: Problems and prospects. J. Manag. 1986, 12, 531-544. [CrossRef]

56. Bryman, A.; Cramer, D. Quantitative Data Analysis with IBM SPSS 17, 18 \& 19: A Guide for Social Scientists; Routledge: London, UK, 2012

57. Kline, R.B. Principles and Practice of Structural Equation Modeling; Guilford Publications: New York, NY, USA, 2015.

58. Guo, L.; Xiao, J.J.; Tang, C. Understanding the psychological process underlying customer satisfaction and retention in a relational service. J. Bus. Res. 2009, 62, 1152-1159. [CrossRef]

59. Hair, J.; Anderson, R.; Tatham, R.; Black, W. Multivariate Data Analysis; Prentice Hall: Saddle River, NJ, USA, 2014.

60. Anderson, J.C.; Gerbing, D.W. Structural equation modeling in practice: A review and recommended two-step approach. Psychol. Bull. 1988, 103, 411. [CrossRef]

61. Joreskog, K.G. Analysis of covariance structures. In The Handbook of Multivariate Experimental Psychology; Cattell, R.B., Nessclroade, J.R., Eds.; Plenum Press: New York, NY, USA, 1988; pp. 207-230.

62. Fornell, C.; Larcker, D. Evaluating structural equation models with unobservable variables and measurement error. J. Mark. Res. 1981, 18, 39-50. [CrossRef]

63. Kelloway, E.K. Structural equation modelling in perspective. J. Organ. Behav. 1995, 16, 215-224. [CrossRef]

64. Zhao, X.; Lynch, J.G., Jr.; Chen, Q. Reconsidering Baron and Kenny: Myths and truths about mediation analysis. J. Consum. Res. 2010, 37, 197-206. [CrossRef]

65. Bartik, A.W.; Bertrand, M.; Cullen, Z.B.; Glaeser, E.L.; Luca, M.; Stanton, C.T. How are Small Businesses Adjusting to Covid-19? Early Evidence from a Survey (No. w26989); National Bureau of Economic Research: Chicago, IL, USA, 2020.

66. Raja, U.; Sheikh, R.A.; Abbas, M.; Bouckenooghe, D. Do procedures really matter when rewards are more important? A Pakistani perspective on the effects of distributive and procedural justice on employee behaviors. Eur. Rev. Appl. Psychol. 2018, 68, 79-88. [CrossRef]

67. Sulemana, I.; Bofah, R.O.; Nketiah-Amponsah, E. Job insecurity and life satisfaction in Ghana. J. Fam. Econ. Issues. 2020, 41, 172-184.

68. Abbas, M.; Malik, M.; Sarwat, N. Consequences of job insecurity for hospitality workers amid COVID-19 pandemic: Does social support help? J. Hosp. Mark. Manag. 2021, 30, 957-981. [CrossRef]

69. Chirumbolo, A.; Hellgren, J. Individual and organizational consequences of job insecurity: A European study. Econ. Ind. Democr. 2003, 24, 217-240. [CrossRef]

70. Emberland, J.S.; Rundmo, T. Implications of job insecurity perceptions and job insecurity responses for psychological well-being, turnover intentions and reported risk behavior. Saf. Sci. 2010, 48, 452-459. [CrossRef]

71. Ghosh, S.K. The direct and interactive effects of job insecurity and job embeddedness on unethical pro-organizational behavior: An empirical examination. Pers. Rev. 2017, 46, 1-17. [CrossRef]

72. Lawrence, E.R.; Kacmar, K.M. Exploring the impact of job insecurity on employees' unethical behavior. Bus. Ethics Q. 2017, 27, 39-70. [CrossRef]

73. Obeng, A.F.; Quansah, P.E.; Boakye, E. The Relationship between Job Insecurity and Turnover Intention: The Mediating Role of Employee Morale and Psychological Strain. Management 2020, 10, 35-45. 
74. Safavi, H.P.; Karatepe, O.M. The effect of job insecurity on employees' job outcomes: The mediating role of job embeddedness. J. Manag. Dev. 2019, 38, 288-297. [CrossRef]

75. Hur, H.; Perry, J.L. The relationship between job security and work attitudes: A meta-analysis examining competing theoretical models. In Proceedings of the APSA 2014 Annual Meeting Paper, Indiana University, Bloomington, CA, USA, 21 August 2014. Bloomington School of Public \& Environmental Affairs Research Paper (No. 2452082).

76. Armstrong-Stassen, M. Determinants of how managers cope with organisational downsizing. Appl. Psychol. 2006, 55, 1-26. [CrossRef]

77. Huang, G.H.; Zhao, H.H.; Niu, X.Y.; Ashford, S.J.; Lee, C. Reducing job insecurity and increasing performance ratings: Does impression management matter? J. Appl. Psychol. 2013, 98, 852. [CrossRef]

78. King, J.E. White Collar Reactions to Job Insecurity and the Role of the Psychological Contract: Implications of Human Resource Management. Hum. Resour. Manag. 2000, 39, 79-92. [CrossRef]

79. Singh, R. Developing organisational embeddedness: Employee personality and social networking. Int. J. Hum. Resour. Manag. 2019, 30, 2445-2464. [CrossRef]

80. Brougham, D. and Haar, J. Technological disruption and employment: The influence on job insecurity and turnover intentions: A multi-country study. Technol. Forecast. Soc. Change 2020, 161, 120276. [CrossRef]

81. Ashford, S.J.; Lee, C.; Bobko, P. Content, cause, and consequences of job insecurity: A theory-based measure and substantive test. Acad. Manag. J. 1989, 32, 803-829.

82. Davy, J.A.; Kinicki, A.J.; Scheck, C.L. Developing and testing a model of survivor responses to layoffs. J. Vocat. Behav. 1991, 38, 302-317. [CrossRef]

83. Elshaer, I.A.; Augustyn, M.M. Testing the dimensionality of the quality management construct. Total. Qual. Manag. Bus. Excell. 2016, 27, 353-367. [CrossRef] 